\section{A White House Conference primer for academic libraries}

\author{
By David B. Walch
}

Member, ACRL Task Force on WHCLIS

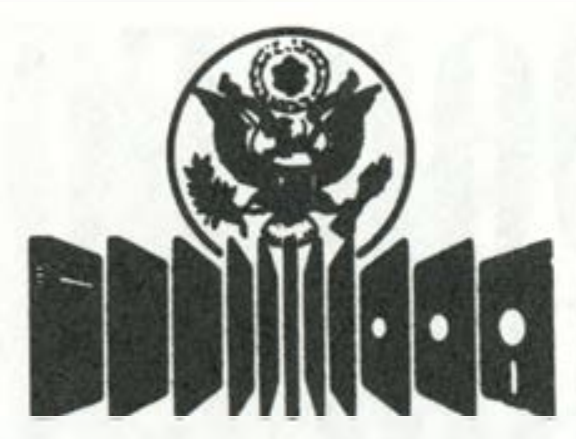

\section{The White House Conference ON LIBRARY AND INFORMATION SERVICES 1991}

The White House Conference on Libraries and Information Services (WHCLIS) was initially conceived some 33 years ago when Channing Bete, a library trustee from Greenfield, Massachusetts, initially proposed the idea. However, four different U.S. Presidents (Johnson, Nixon, Ford, and Carter) were to preside over this nation before the first Conference was held in November 1979. More than 100,000 people participated in preconference activities including those held in each of the 57 states and territories. These preconferences elected more than 600 official delegates. An additional 4,000 attendees, including alternate delegates, observers, volunteers and staff, made it the largest White House Conference ever held.

The 1979 Conference focused on five themes:

1. Meeting personal needs.

2. Enhancing lifelong learning.

3. Improving organizations and professions.

4. Effectively governing our society.

5. Increasing international understanding and cooperation.

By the end of the conference 49 resolutions had been considered, 25 of which passed. Among other things, the resolutions called for greater library visibility within the Department of Education, broader information access for all Americans, library services without charge in publicly supported institutions, network sharing, more national coordination, increased funding, and the convening of a White House Conference on Library and Information Services every decade.

Assessment regarding the success of the Conference was mixed. Noteworthy resolutions related to the five themes and other critical issues were passed. Political leaders at all levels, including the President of the United States, were involved in one way or another. Leaders from "information organizations," including ALA, the Information Industry Association, the Association of American Publishers, the Association of Research Libraries, and others were present. Some have suggested, however, that while the Conference underscored the importance of what the library world was al- ready working on, it failed to develop any creative new concepts and that while major news magazines provided moderate coverage, the coverage did not focus world attention on libraries.

The success of the Conference was also mixed so far as academic libraries were concerned. Much of the discussion was in the context of public libraries. The Conference did mention college and university libraries, but there were no academic library issues discussed per se. Only 33 academic librarians were included in the more than 900 delegates and alternates.

The 1979 Conference passed a resolution recommending that a White House Conference be held each decade "to establish national information goals and priorities for the next decade." To that end a law was passed that authorized the President to call a second Conference to "develop recommendations for the further improvement of the library and information services of the nation and their use by the public." This second White House Conference is scheduled for July 9-13, 1991.

As preparations are made for this event it is important for academic librarians to be aware of the following fundamentals.

\section{Key organizations}

National Commission on Libraries and Information Science (NCLIS)

The Commission is a permanent, independent federal agency created to advise the government on national library and information policies and plans. It is the parent organization for the White House Conference. An academic librarian, Julia L. $\mathrm{Wu}$, Los Angeles Community College District, is a member of the Commission.

White House Conference Advisory Committee (WHCAC)

This Committee is composed of 30 members who are appointed ( 8 by the chair of NCLIS, five by the Speaker of the House, five by the President pro tem of the Senate, ten by the President; the Secretary of Education and Librarian of Congress are 


\section{FOOD FOR THOLLGHIT}

For a taste of what's cooking in sociology, applied social sciences, and linguistics, dip into sociological abstracts (sa), Social Planning/Policy \& Development Abstracts (SOPODA) or Linguistics and Language Behavior Abstracts (LLBA).

sa, SOPODA, and LLBA transcend linguistic boundaries to bring you in-depth abstracts from 1,800 core and ancillary journals published worldwide.

sa and SOPODA are available in three eminently palatable formats: online from BRS, Dialog, Data-Star, and DIMDI; in print; and now, together for the first time, on the sociofile compact disc.

LLBA can be accessed online via $B R S$ and Dialog, and appears in print quarterly.

A variety of user aids including user's manuals and the sa Thesaurus of Sociological Indexing Terms (2nd Edition, 1989) will add special flavor to your searches.

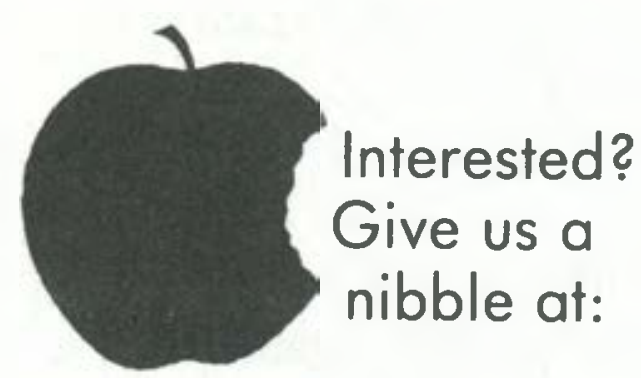

\section{sociological abstracts, inc.}

P.O. Box 22206

San Diego, CA 92122-0206

(619) 695-8803

FAX: (619) 695-0416 members by statute). The purpose of the Committee is to assist and advise NCLIS in planning and conducting the Conference. Two academic librarians are on this Committee: Stuart Forth, dean emeritus of Pennsylvania State University Libraries, and Gloria Hom, Mission College.

\section{Preconferences}

Each state and territory, the District of Columbia, the American Indian Tribes, and the federal library community will hold preconference activities to identify library and information science issues that need to be addressed. It is intended that these preconferences generate a broad grassroots involvement that will assume consideration of a wide range of library and information needs. Many of these will be of concern at the state and territorial level and will provide a future agenda for local consideration. Others will have a national thrust and be taken to the White House Conference for further discussion and debate.

\section{Delegates}

More than 600 official voting delegates to the Conference will be chosen by their respective states and territories. 25\% will represent library and information professionals; $25 \%$ will represent government officials at all levels; $25 \%$ will represent friends, trustees, and other library supporters; and $25 \%$ will represent the general public.

\section{Theme}

The three-fold theme for the Conference is to develop recommendations for the further improvement of library and information services that will serve to increase productivity, expand literacy, and strengthen democracy.

\section{The role of academic librarians}

Academic librarians must adopt a high profile for the second White House Conference. Find out when your state is holding its preconference (see the listing in C $\mho R L$ News, June 1990, p.521, or call WHCLIS at (202) 254-5100), determine how delegates are being selected, and develop issues that can be taken to the preconference for consideration at both the state and federal level. Re-read the ACRL Task Force's position paper in C $\&$ RL News, September 1990, pp. 713-15.

For additional information contact Patricia Wand, chair of the ACRL Task Force on WHCLIS, (202) 885-3237, or any other of its members: David F. Bishop, Hiram Davis, Joan Chambers, Stuart Forth, Sharon A. Hogan, Cerise G. Oberman, and David B. Walch. 